\title{
Pengenalan tradisi Laras Madya dalam pembelajaran IPS melalui pendekatan konstruktivisme
}

\author{
Moch. Dimas Galuh Mahardika \\ Fakultas Keguruan dan Ilmu Pendidikan, Universitas Sebelas Maret \\ Surakarta, Indonesia \\ dimas.dg20@gmail.com \\ Sariyatun \\ Fakultas Keguruan dan Ilmu Pendidikan, Universitas Sebelas Maret \\ Surakarta, Indonesia \\ sariyatun@staff.uns.ac.id
}

\begin{abstract}
Social science learning is an effort to provide student's knowledge and comperhension about social condition in daily life. Basicly, social science is an integration of the study of social science such as, history, geography, economics, politic, sociology and other humanities science. So, the main purpose of social science learning to create the humans who are aware of their position as members of civil society. The introduction of local tradition also needs to be included in gerenal material on social science learning. Students are able to know more about existence of local tradition, one of wich is Laras Madya tradition. Laras Madya tradition is a one of the local tradition that can be inserted into the general social science learning materials. The approach to introduce this tradition is constructivism. Constructivism is an effective approach to use because can provides sufficient space for student to actively seek, collect, and process information to build their knowledge. This article is the author's conceptual idea wich aims to provide a new reference about local tradition.
\end{abstract}

Keywords: social science learning; Laras Madya tradition; constructivism

\begin{abstract}
Abstrak
Pembelajaran IPS merupakan satu kiat di dalam memberikan pemahaman dan pengetahuan tentang kehidupan sosial di dunia nyata kepada siswa. Pada hakikatnya, IPS merupakan integrasi kajian ilmu-ilmu sosial seperti sejarah, geografi, ekonomi, politik sosiologi dan ilmu humaniora lainnya. Maka tujuan utama pembelajaran IPS adalah untuk menciptakan manusia yang sadar akan posisinya sebagai anggota masyarakat dan warga negara. Pengenalan tradisi lokal juga perlu untuk disisipkan dalam materi umum IPS supaya siswa mampu mengenal lebih jauh tradisi lokal yang ada, salah satunya tradisi Laras Madya. Laras Madya merupakan salah satu tradisi lokal yang dapat disisipkan di dalam materi umum IPS. Pendekatan yang digunakan untuk mengenalkan tradisi ini adalah pendekatan konstruktivisme. Konstruktivisme dianggap efektif untuk digunakan karena pendekatan ini memberikan ruang yang cukup luas untuk siswa aktif dalam mencari, mengumpulkan, dan mengolah informasi guna membangun pengetahuan mereka. Artikel ini merupakan gagasan konseptual penulis yang bertujuan untuk
\end{abstract}


memberikan pengetahuan baru terkait dengan tradisi lokal dan untuk memberikan referensi baru dalam pembelajaran IPS.

Kata Kunci: Pembelajaran IPS; Laras Madya; Konstruktivisme

\section{PENDAHULUAN}

IPS merupakan suatu program pendidikan dan bukan sub-disiplin ilmu tersendiri, sehingga tidak akan ditemukan baik dalam nomenklatur filsafat ilmu, disiplin ilmu-ilmu sosial (social science), maupun ilmu pendidikan (Sumantri, 2001). Social Scense Education Council (SSEC) dan National Council for Social Studies (NCSS), menyebut IPS sebagai "Social Science Education" dan "Social Studies". Ilmu Pengetahuan Sosial merupakan terjemahan dari Social Studies. Social Studies kajian ilmu-ilmu sosial yang diintegrasikan untuk tujuan pendidikan meliputi aspek-aspek ilmu sejarah, ilmu ekonomi, ilmu politik, sosiologi, antropologi, psikologi, ilmu geografi dan filsafat yang dalam praktiknya dipilih untuk tujuan pembelajaran di sekolah dan perguruan tinggi (Nasution \& Lubis, 2018). Secara luas, pengertian social studies mengandung hal-hal sebagai berikut: (a) Social Studies merupakan turunan dari ilmu-ilmu sosial; (b) disiplin IPS dikembangkan untuk memenuhi tujuan pendidikan pada tingkat sekolah maupun tingkat perguruan tinggi; (d) aspek-aspek dari masing-masing disiplin ilmu sosial itu perlu diseleksi sesuai dengan tujuan tersebut.

Meskipun pengetahuan sosial sesungguhnya sudah melekat pada diri seseorang, IPS perlu dipelajari dan diajarkan kepada peserta didik. Pengetahuan sosial alamiah itu belum cukup untuk memahami kehidupan masyarakat dengan segala persoalannya yang kian hari semakin berkembang. Untuk menghadapi perkembangan yang dinamis dan bersifat kontinyu tersebut diperlukan pendidikan formal yang mengkaji secara spesifik tentang kehidupan sosial manusia, yakni pendidikan IPS di sekolah.

Pendidikan IPS dikembangkan atas dasar pemikiran bahwa pendidikan IPS merupakan suatu disiplin ilmu. Oleh karena itu pendidikan IPS harus mengacu pada tujuan pendidikan nasional. Tujuan pendidikan IPS adalah mengembangkan kemampuan peserta didik dalam menguasai disiplin ilmu-ilmu sosial untuk mencapai tujuan pendidikan yang lebih tinggi (Bucchi, 2004). Menurut Hasan (1996) menyatakan bahwa tujuan pendidikan IPS dapat dikelompokkan ke dalam tiga kategori, yaitu pengembangan kemampuan intelektual siswa, pengembangan kemampuan dan rasa tanggung jawab sebagai anggota masyarakat dan bangsa 


\section{Pengenalan tradisi Laras Madya dalam pembelajaran IPS melalui pendekatan konstruktivisme}

serta pengembangan diri siswa sebagai pribadi. Tujuan pertama berorientasi pada pengembangan kemampuan intelektual yang berhubungan dengan diri siswa dan kepentingan ilmu pengetahuan khususnya ilmu-ilmu sosial. Tujuan kedua berorientasi pada pengembangan diri siswa dan kepentingan masyarakat. Sedangkan tujuan ketiga lebih berorientasi pada pengembangan pribadi siswa baik untuk kepentingan dirinya, masyarakat maupun ilmu.

Pendidikan IPS bertujuan membina peserta didik menjadi warga negara yang baik, dengan berbekal pengetahuan, keterampilan dan kepedulian sosial, yang berguna bagi dirinya sendiri serta bagi lingkungan sekitarnya. Untuk merealisasikan tujuan ini maka proses pembelajaran IPS tidak hanya menekankan pada aspek pengetahuan (kognitif), dan keterampilan (psikomotor) saja, melainkan meliputi juga aspek sikap dan moral (afektif) dalam menghayati serta menyadari kehidupan yang penuh dengan masalah, tantangan, hambatan, dan persaingan. Melalui pendidikan IPS peserta didik dibina dan dikembangkan kemampuan mental intelektualnya menjadi warga Negara yang berketerampilan dan berkepedulian sosial serta bertanggung jawab sesuai dengan nilai-nilai yang terkandung dalam Pancasila.

Fokus kajian Pendidikan IPS adalah kehidupan manusia dengan sejumlah aktivitas sosialnya. Materi pendidikan IPS berasal dari disiplin ilmu-ilmu sosial yang kemudian diorganisasi dan disederhanakan untuk kepentingan pendidikan. Dengan demikian pengembangan pendidikan IPS pada setiap jenjang pendidikan memiliki karakteristik tersendiri yang disesuaikan dengan tingkat perkembangan usia siswa. Tradisi pengembangan pendidikan IPS di Indonesia banyak dipengaruhi oleh tradisi pengembangan social studies di Amerika Serikat. Hal ini disebabkan karena Amerika Serikat merupakan salah satu Negara yang memberikan perhatian yang sangat besar dalam pengembangan kajian sosial. Amerika Serikat merupakan Negara yang sangat plural, terdiri dari berbagai ras, bangsa, agama, dan kebudayaan sehingga masyarakatnya bersifat multikultural. Kondisi semacam ini juga terjadi di Indonesia, di mana masyarakat Indonesia juga memiliki komposisi masyarakat beragam terdiri dari berbagai suku bangsa, budaya, agama, dan sebagainya. Di tengah kondisi masyarakat yang plural dengan serba keberagaman inilah maka diperlukan adanya perhatian khusus dalam pengembangan kajian sosial (Kymlicka, 1995).

Penetapan materi pendidikan IPS yang akan diberikan kepada siswa disusun dan direncanakan sedemikian rupa yang memperhatikan teori dan konsep serta landasan filosofis, 
akademik dan edukatif. Kesemuanya itu tentu saja akan diarahkan pada tujuan-tujuan yang telah ditetapkan dalam pendidikan IPS. Materi IPS juga perlu dikembangkan sesuai dengan konteks sosio kultural peserta didik dengan mengenalkan tradisi-tradisi lokal yang ada. Seperti halnya tradisi Laras Madya yang merupakan keberlanjutan dari tradisi Santiswaran yang ada di Surakarta. Santiswaran merupakan kegiatan keagamaan yang dikenalkan oleh Adipati Sastraningrat dan Patih Dalem Keraton Surakarta pada awal abad XX. Tradisi ini berisi tentang nyanyian lagu rohani dengan iringan terbang yang dimainkan setiap Ahad pukul 20.00-24.00 di Kedhaton (Bakri, 2015; Houben, 2002).

Artikel ini ditulis dengan tujuan untuk mengelaborasi pengenalan tradisi Laras Madya dalam pembelajaran IPS melalui pendekatan konstruktivisme. Konstruktivisme merupakan landasan transisi dalam pendekatan pembelajaran dari teaching oriented menjadi student centered. Dalam pandangan konstruktivisme, pengetahuan tidak dapat ditransfer begitu saja. Maka harus ada stimulan dari guru supaya siswa mampu membangun pengetahuan mereka secara mandiri (Mu'ammar, 2019). Mengingat pembelajaran IPS merupakan sebuah upaya untuk memberikan pemahaman intelektual dan kognisi sosial kepada peserta didik, maka artikel ini dapat dijadikan tambahan wawasan dan perspektif para pengajar IPS di dalam mengintegrasikan tradisi dan kearifan lokal di tengah materi umum pembelajaran IPS.

\section{METODE}

Artikel ini merupakan gagasan konseptual yang ditulis dengan menggunakan metode kepustakaan. Menurut Zed (2004) beberapa prinsip penelitian kepustakaan di antaranya: a) berhadapan langsung dengan teks; (b) bersifat siap pakai; (c) sumber yang digunakan pada umumnya adalah sumber sekunder. Sumber yang terkumpul kemudian diidentifikasi secara substansial untuk menyeleksi teori-teori yang dianggap sesuai untuk dijadikan landasan dalam penulisan artikel ini, sehingga interpretasi yang dilakukan setelah meninjau sumber dapat tepat sasaran. Maka beberapa rujukan yang digunakan di antaranya 20 buku dan 3 jurnal yang dianggap relevan dengan pembahasan pada artikel ini untuk memberikan referensi kepada penulis supaya pembahasan di dalam artikel ini dapat menjelaskan gagasan yang diusung penulis seputar pendekatan konstruktivisme dalam pembelajaran IPS untuk mengenalkan kearifan lokal. 


\section{HASIL DAN PEMBAHASAN Tradisi Laras Madya}

Tradisi Laras Madya merupakan tradisi keagamaan yang berisi tentang pujaan terhadap Nabi Muhammad SAW atau yang biasa dikenal sebagai shalawatan. Tradisi shalawatan mulai banyak dilakukan di lingkungan keraton Surakarta pada masa Paku Buwana IV, ia merupakan pemeluk agama Islam yang taat. Dalam praktiknya ia sering mengadakan pemurnian praktik agama Islam dengan memberikan khotbah di masjid serta memberikan contoh "sembah" yang baik dan sempurna kepada seluruh masyarakat (Sumarsam, 1992). Selain itu Paku Buwana IV juga melakukan praktik ajaran agama Islam melalui bentuk kesenian seperti pertunjukan wayang dengan cerita-cerita bernafaskan Islam dan seni terbangan (Panggiyo, 2004).

Paku Buwana IV juga aktif di dalam kegiatan literasi. Ia menulis beberapa serat dalam bentuk tembang macapat di antaranya: Dhandanggula, Mijil, Sinom, Masukmambang, Wirangong, Gambuh, Megatruh, Durma, Kinanthi, Pangkur, Pocung dan Asmaradana (Panggiyo, 2004). Tulisan-tulisan tersebut dijadikan satu ke dalam sebuah buku yang berjudul Serat Wulangreh. Buku tersebut berisi tentang ajaran Islam yang membahas tentang kesusilaan secara praktik dan beberapa nilai hasil penghayatan dan pengamalan Al-Qur'an (Ciptoprawiro, 1986).

Pada sisi yang lain, ternyata tembang-tembang yang diciptakan oleh Paku Buawana IV juga berisi tentang nilai-nilai keadilan dan memiliki kecenderungan bersifat anti penjajah. Sehingga gerakan keagamaan tersebut selalu diamati sampai sempat terjadi pengecaman oleh pemerintah kolonial. Pemerintah memiliki kewaspadaan penuh kepada para pemimpin agama, termasuk raja sebagai pemimpin. Kewaspadaan itu muncul karena pemerintah kolonial menganggap bahwa Islam sebagai ideologi yang berbahaya ketika ajarannya dibiarkan berkembang di kalangan masyarakat sipil (Ricklefs, 2007). Sehingga hal tersebut mendorong pemerintah untuk melakukan pengawasan ketat dan melakukan pembatasan kepada aktivitas keagamaan yang dianggap mengancam stabilitas politik pemerintah kolonial. Pasca Paku Buwana IV wafat pada 1820, kesenian ini hampir sama sekali tidak ditemui. Mungkin saja pemerintah kolonial memberikan larangan untuk kegiatan ini mengingat lima tahun pasca kepergian Paku Buwana IV terjadi perang Jawa yang dimulai pada tahun 1825 dan berakhir pada 1830. Perang tersebut membuat berbagai kekacauan dalam bidang sosial, politik dan 


\section{Moch. Dimas Galuh Mahardika \& Sariyatun}

ekonomi. Maka untuk menjaga kestabilan politik, pemerintah kolonial harus meningkatkan kewaspadaan kepada semua kalangan, khususnya kalangan Islam dan santri karena perang Jawa juga diinisiasi oleh Pangeran Diponegoro yang notabene adalah penganut Islam yang kuat (Carey, 2011).

Kesenian ini kembali muncul ketika masa pemerintahan Paku Buwana X yang diinisiasi oleh Adipati Sastraningrat. Tradisi tersebut kemudian diberi nama santiswaran. Adipati Sastradiningrat kemudian menyusun kembali lagi dan syair ditambah dengan iringan terbangan yang terdiri dari dua buah kemanak sebagai instrumennya dan diberi istilah baru yakni Laras Madya (Panggiyo, 2004). Kesenian ini terus berlanjut dan masih tetap eksis sampai era kemerdekaan dan pasca kemerdekaan. Pada masa ini, Laras Madya digelar pada hari Jum'at yang notabene dianggap sebagai hari sakral umat Islam. Tradisi ini kemudian dikembangkan oleh para pemuka agama setempat seperti kyai, tetua desa, dan pemimpin desa beragama Islam yang dihormati.

Laras Madya di dalam konteks kesenian merupakan suatu bentuk ekspresi masyarakat atas kebudayaan luhur yang sengaja diwariskan secara turun temurun (Geertz, 1973). Tradisi ini juga merupakan salah satu bentuk konkret dari apa yang disebut sebagai psikologi eksperimental (pengalaman keindahan) manusia sehingga dapat menciptakan sebuah karya seni bernilai estetis tinggi (Waesberghe, 2016). Keberadaannya kini dapat disebut sebagai folk art, yang dihasilkan dari peradaban kebudayaan luhur masyarakat (Adzkia, 2016). Folk art merupakan sebuah klasifikasi jenis kesenian yang didasarkan pada nilai-nilai sebuah komunitas masyarakat tradisional di luar konteks kesenian populer (Hauser, 1982).

Struktur musik Laras Madya memiliki sebuah kesatuan ansambel dari beberapa instrumen seperti, kendang, dhana, terbang gong dan saron dan satu pelantun tembang yang berisi syair dari Serat Wulangreh (Adzkia, 2016). Laras Madya biasanya digelar pada saat ritual keagamaan seperti selametan, ruawtan, ruwahan, maleman sampai dengan ritual hajat untuk perkawinan (Panggiyo, 2004). Hal ini merupakan salah satu bentuk akulturasi antara ajaran Islam dengan tradisi Jawa. Orang-orang Jawa sudah sejak dahulu kala sudah memiliki ritualritual tersebut, karena mereka memiliki anggapan bahwa setiap kejadian baik dan buruk harus diperingati dengan ritual dengan tujuan untuk selalu mendapatkan kedamaian hidup (Geertz, 1976). Dalam aspek sosial, tradisi ini juga mencerminkan interaksi dan kerukunan sosial antar 


\section{Pengenalan tradisi Laras Madya dalam pembelajaran IPS melalui pendekatan konstruktivisme}

masyarakat. Mengingat orang Jawa merupakan kelompok masyarakat komunal yang memiliki adab dan sikap yang santun dan berwatak gotong-royong.

\section{Pengenalan Laras Madya dalam Pembelajaran IPS Melalui Pendekatan}

\section{Konstruktivisme}

IPS dirumuskan berlandaskan pada realitas dan fenomena sosial yang diwujudkan dengan pendekatan interdisipliner dari cabang ilmu-ilmu sosial. Hakikat IPS adalah untuk mengembangkan konsep pemikiran yang berdasarkan realitas kondisi sosial yang ada di lingkungan siswa, sehingga pendidikan IPS diharapkan dapat melahirkan warga negara memiiki daya intelektual dan kecakapan sosial yang mumpuni. Pendidikan IPS saat ini dihadapkan pada suatu upaya peningkatan kualitas pendidikan khususnya sumber daya manusia, sehingga eksistensi pendidikan IPS benar-benar dapat mengembangkan pemahaman konsep dan keterampilan berpikir kritis. Meskipun demikian, kenyataan di lapangan masih menunjukkan banyaknya anggapan bahwa pendidikan IPS kurang memiliki kegunaan yang besar bagi siswa dibandingkan pendidikan IPA dan Matematika yang mengkaji bidang sains dan teknologi (Endayani, 2018).

Tujuan pembelajaran IPS adalah mengembangkan potensi peserta didik agar mereka memiliki kepekaan terhadap fenomena sosial yang terjadi di masyarakat, serta memiliki sikap mental positif untuk melatih keterampilan dalam mengatasi setiap masalah yang terjadi di kehidupan nyata baik yang menimpa diri sendiri atau masyarakat. Menurut NCSS, tujuan utama dari mempelajari IPS adalah membantu peserta didik sebagai warga negara dalam membuat keputusan yang rasional berdasarkan informasi untuk kepentingan publik atau umum dari masyarakat demokratis dan budaya yang beragam di dunia yang saling tergantung (Astawa, 2017). Pengembangan keterampilan intelektual siswa harus diberangi dengan pengembangan kognisi sosial sebagai bentuk aplikasi dari tujuan pembelajaran IPS. Siswa diharapkan mampu memahami lingkungan sekitarnya dengan mengaitkan materi yang telah mereka pelajari dalam pembelajaran IPS.

Paradigma baru dalam pembelajaran abad 21 ini selalu menggaungkan pemusatan aktivitas belajar kepada siswa dan mengurangi dominasi guru dalam kegiatan pembelajaran. Maka diperlukan sebuah pendekatan khusus di dalam pembelajaran IPS untuk mendukung 
aktivitas belajar siswa yang berorientasi pada kecakapan intelektual dan kecakapan kognisi sosial (Schiering dkk., 2011). Pembelajaran yang berpusat pada aktivitas siswa harus didukung dengan strategi pembelajaran yang mumpuni. Guru harus mempersiapkan rancangan pembelajaran yang sesuai supaya tujuan yang diharapkan dapat tercapai. Selain itu, posisi guru dalam hal ini adalah menjadi pembimbing, partner belajar dan fasilitator siswa. Artinya meskipun pembelajaran berpusat pada aktivitas siswa, guru tidak serta merta membiarkan siswa untuk belajar sendiri. Arahan dan pendampingan perlu diberikan supaya siswa tetap berada pada alur pembelajaran yang sudah direncanakan guru. Selain itu, di dalam mengakses informasi siswa juga perlu diberikan arahan dan pengertian supaya mereka dapat menyeleksi sumber-sumber yang digunakan.

Pada subbab sebelumnya telah dijabarkan tentang tradisi Laras Madya, dan materi tersebut diharapkan dapat diintegrasikan dalam materi pembelajaran IPS untuk mengenalkan tradisi lokal kepada siswa. Untuk mengajarkan hal itu, penulis memiliki sebuah gagasan dengan menggunakan pendekatan konstruktivisme. Pembelajaran berbasis konstruktivisme menurut (Woolfolk, 2004) harus memenuhi unsur-unsur berikut:

1. Menggunakan sumber primer, perumusan hipotesis, dan keterlibatan dalam kegiatan pembelajaran yang sistematis

2. Adanya upaya untuk memahami perbedaan pandangan/perspektif

3. Menjadi pebelajar yang sadar akan literasi (membaca, dan menulis)

4. Memiliki keberanian dan kemampuan menghadapi masalah

Pembelajaran IPS dengan menggunakan pendekatan konstruktivisme diharapkan mampu memberikan dorongan kepada siswa untuk belajar secara mandiri dalam rangka memenuhi tuntutan dari Kurikulum 2013 yang berorientasi pada pemusatan siswa sebagai poros kegiatan pembelajaran. Oleh karena di dalam pendekatan konstruktivisme sangat memungkinkan siswa untuk belajar secara mandiri, maka perlu dirancang susunan kegiatan pembelajaran yang mampu mendukung orientasi tersebut di dalam praktiknya.

Berikut skema pembelajaran mengenai pengenalan tradisi Laras Madya dalam pembelajaran IPS melalui pendekatan konstruktivisme (Lihat gambar 1). 

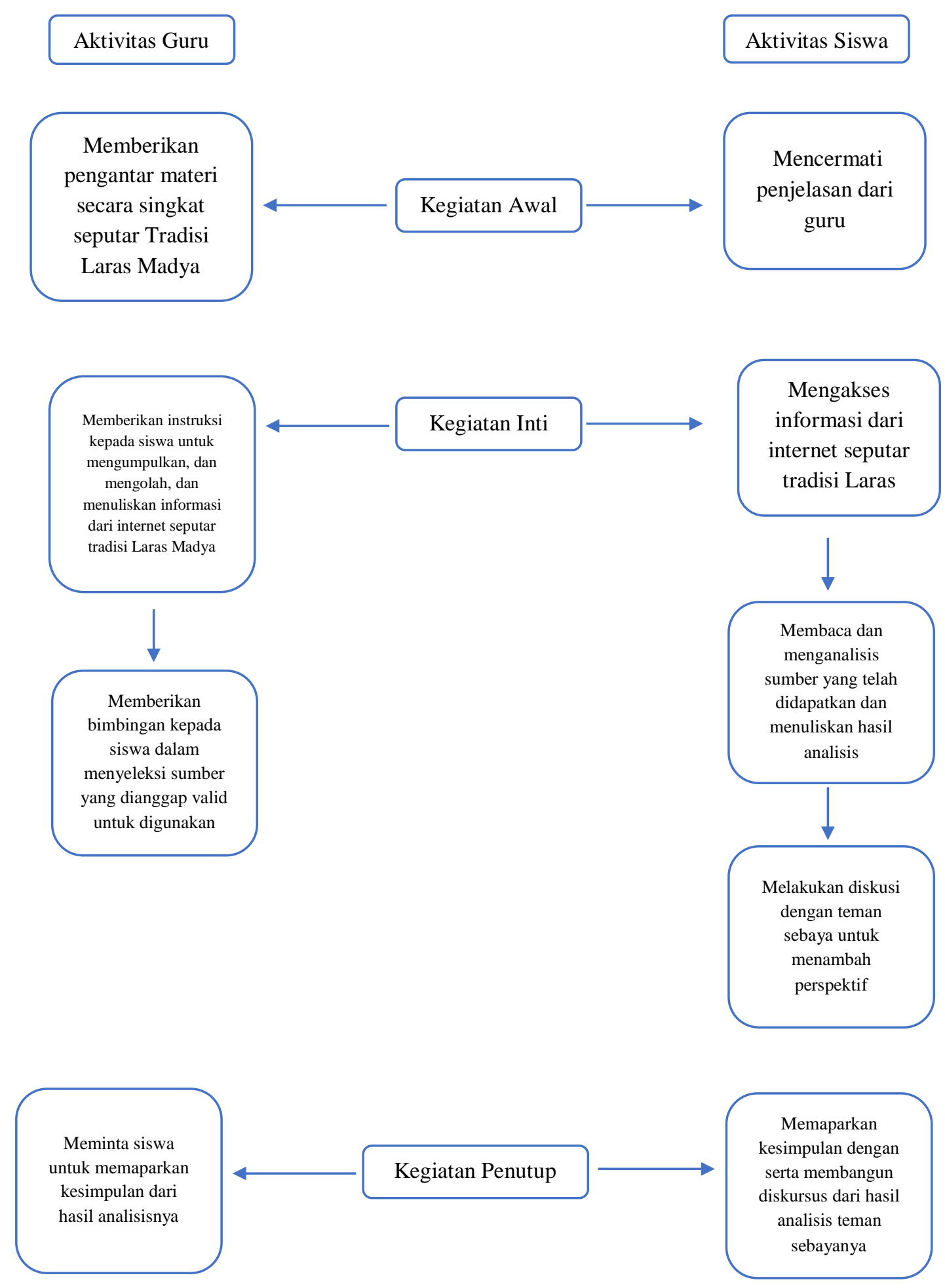

Gambar 1. Skema Pembelajaran Menggunakan Pendekatan Konstruktivisme 
Skema tersebut menjelaskan bahwa alur pembelajaran dengan menggunakan pendekatan konstruktivisme tidak memposisikan guru dalam posisi yang dominan. Aktivitas belajar siswa ditunjang dengan instruksi guru untuk belajar mandiri. Meskipun demikian peran guru tidak hilang sama sekali, ia hanya bertugas untuk membimbing dan membantu siswa apabila mereka menemui kesulitan. Berikutnya, aktivitas belajar siswa dalam pembelajaran tersebut mendorong siswa untuk memiliki kecakapan dalam membangun pengetahuan mereka sendiri. Mereka dilatih untuk dapat menyeleksi informasi yang dianggap sesuai dengan materi yang sedang mereka pelajari. Selain itu siswa juga diajari untuk memiliki keterampilan sosial yang baik dengan berdiskusi bersama teman sebayanya untuk saling bertukar pikiran dan menambah perspektif.

\section{SIMPULAN}

Pembelajaran IPS disusun untuk membangun pengetahuan dan membentuk kognisi sosial siswa. Integrasi kajian ilmu-ilmu sosial di dalam pembelajaran IPS merupakan salah satu bentuk konkret bahwa kebutuhan belajar siswa harus diarahkan kepada sesuatu yang bersifat teoritik di dalam pembelajarannya, dan bersifat praktis di dalam implementasinya. Maka dari itu tujuan pembelajaran IPS adalah untuk menciptakan kepekaan sosial siswa terhadap lingkungan di sekitarnya, salah satunya adalah mengenali hasil-hasil budaya yang ada seperti tradisi lokal. Peran guru dalam hal ini cukup penting di dalam mengenalkan tradisi lokal yang ada. Guru harus merencanakan kegiatan pembelajaran yang dapat menunjang aktivitas siswa di dalam mengenal tradisi-tradisi lokal.

\section{DAFTAR PUSTAKA}

Adzkia, S. F. (2016). Analisis Bentuk Musik atas Kesenian Laras Madya dan Resistensinya dalam Budaya Jawa. PROMUSIKA: Jurnal Pengkajian, Penyajian, Dan Penciptaan Musik, 4(1), 1-12.

Astawa, I. B. M. (2017). Pengantar Ilmu Sosial. Rajawali Press.

Bakri, S. (2015). Gerakan Komunisme Islam Surakarta 1914-1942 (Cetakan I). Penerbit \& distribusi, LKiS Pelangi Aksara.

Bucchi, M. (2004). Science in Society: An Introduction to Social Studies of Science (1st English 


\section{Pengenalan tradisi Laras Madya dalam pembelajaran IPS melalui pendekatan konstruktivisme}

language ed). Routledge.

Carey, P. (2011). Kuasa Ramalan: Pangeran Diponegoro dan Akhir Tatanan Lama di Jawa, 1785-1855. Kepustakaan Populer Gramedia.

Ciptoprawiro, A. (1986). Filsafat Jawa. Balai Pustaka.

Endayani, S. H. (2018). Sejarah dan Konsep Pendidikan IPS. Jurnal Ittihad, 2(2), 117-126.

Geertz, C. (1973). The Interpretation Of Cultures. Basic Books.

Geertz, C. (1976). The Religion of Java. University of Chicago Press.

Hasan, S. H. (1996). Pendidikan Ilmu Sosial. Dirjendikti, Depdikbud RI.

Hauser, A. (1982). The Sociology of Art. The University of Chicago Press.

Houben, V. J. H. (2002). Keraton dan Kompeni: Surakarta dan Yogyakarta 1830-1870. Bentang Budaya.

Kymlicka, W. (1995). Multicultural Citizenship: A Liberal Theory of Minority Rights. Clarendon Press ; Oxford University Press.

Mu'ammar, M. A. (2019). Nalar Kritis Pendidikan. IRCiSoD.

Nasution, T., \& Lubis, M. A. (2018). Konsep Dasar IPS. Samudra Biru.

Panggiyo. (2004). Seni Larasmadya Desa Wonorejo Kabupaten Sukoharjo. Keteg, 4(1), 4153.

Ricklefs, M. C. (2007). Sejarah Indonesia Modern. Serambi Ilmu.

Schiering, M. S., Bogner, D., \& Buli-Holmberg, J. (2011). Teaching and Learning: A Model for Academic and Social Cognition. Rowman \& Littlefield Education.

Sumantri, M. N. (2001). Menggagas Pembaharuan Pendidikan IPS. PT Remaja Rosdakarya.

Sumarsam. (1992). Historical Context and Theories Javanese Music. Cornell University.

Waesberghe, F. H. S. (2016). Estetika Musik. Thafa Media.

Woolfolk, A. (2004). Educational Psychology. Pearson.

Zed, M. (2004). Metode Peneletian Kepustakaan. Yayasan Obor Indonesia. 